Pobrane z czasopisma Annales $\mathrm{H}$ - Oeconomia http://oeconomia.annales.umcs.pl

Data: 26/04/2023 14:34:06

DOI:10.17951/h.2017.51.3.85

\begin{tabular}{lcl}
\hline \multicolumn{1}{c}{ A N N A L E S } \\
UNIVERSITATIS MARIAE CURIE-SKŁODOWSKA \\
LUBLIN - POLONIA \\
VOL. LI, 3 & SECTIO H \\
\hline
\end{tabular}

Maria Curie-Skłodowska University in Lublin, Faculty of Economics

PIOTR MALESZYK

ekonomia.maleszyk@gmail.com

\title{
Cooperation between Vocational Schools and Business in Poland: Employers'Perspective
}

Współpraca szkół zawodowych z biznesem: perspektywa pracodawców

Keywords: vocational education and training; employers and VET; comparative VET; VET and the labour market

Słowa kluczowe: kształcenie zawodowe; pracodawcy a kształcenie zawodowe; kształcenie zawodowe; studia porównawcze; kształcenie zawodowe a rynek pracy

\section{JEL code: J21; D22}

\section{Introduction}

The implementation of dual education in Poland encounters numerous barriers. The most common arguments indicate poor organisation of vocational education ${ }^{1}$. Less frequent are the remarks concerning factors connected with the economic and social environment of schools. The aim of the article is to identify those factors and resulting barriers in cooperation between vocational schools and employers. In

1 See e.g. M. Kabaj, System ksztatcenia zawodowego i kierunki jego doskonalenia $w$ warunkach integracji i wzrostu konkurencyjności: Diagnoza i elementy programu szerszego wdrożenia dualnego systemu kształcenia w Polsce, Związek Rzemiosła Polskiego, Warszawa 2010; U. Jeruszka (ed.), Unowocześnienie metod i form ksztatcenia zawodowego w Polsce. Diagnoza i oczekiwane kierunki zmian, IPiSS, Warszawa 2012; NIK, System szkolnictwa zawodowego, Warszawa 2016. 
addition, achievement of the research purpose could contribute to the formulation of the view on the effects of the reform of vocational education in Poland. It might also allow for the identification of these forms of cooperation between schools and employers which should be supported by EU structural funds.

The main source of information on employers' perspective is a survey of employers cooperating with vocational schools in Lublin (Poland). The first section of the article summarizes survey results, whereas the second paragraph presents discussion on the reasons for the limited willingness of employers to cooperate with vocational schools.

\section{Cooperation of employers with vocational schools in the city of Lublin - research results}

The research has covered employers collaborating with vocational schools located in the city of Lublin. A survey was carried out in February 2016 by means of the Computer-Assisted Web Interview (CAWI). The link to an anonymous questionnaire consisting of 14 questions (mainly closed ones) was sent through vocational schools in Lublin to employers who provided vocational training in the school year 2014/2015. As a result, 95 complete questionnaires were obtained. Such scope of research allowed for obtaining information of high substantive value from the employers who already have knowledge about the functioning of vocational schools and have experience in cooperation with them. This is a significant advantage over the majority of surveys on vocational education conducted in Poland among entrepreneurs ${ }^{2}$, which used samples representing enterprises in general, thus predominantly the firms with no experience in cooperation with vocational schools.

Table 1 presents the structure of entities participating in the survey. Comparing the structure of respondents to the structure of business entities in the city of Lublin, it can be observed that there is a relatively high proportion of large and medium entities. Such a situation confirms positive correlation between the size of a company and readiness to cooperate with vocational schools, a relation which has already been documented in literature ${ }^{3}$. The relatively bigger representation of industry and construction companies also remains consistent with empirical findings indicating a higher tendency of enterprises in this sector to cooperate with schools ${ }^{4}$.

2 Instytut Badań Rynku, Konsumpcji i Koniunktur, Absolwenci szkolnictwa zawodowego w Lublinie i Chetmie wobec sytuacji na rynku pracy, Warszawa 2010; Krajowy Ośrodek Wspierania Edukacji Zawodowej i Ustawicznej, Badanie funkcjonowania systemu kształcenia zawodowego w Polsce. Raport końcowy, Warszawa 2011; M. Kicia, R. Zajkowski, Uwarunkowania wspótpracy zasadniczych szkół zawodowych i pracodawców w województwie lubelskim. Raport z badania kluczowego, Fundacja PAN, Lublin 2012.

3 See e.g. M. Canning, M. Godfrey, D. Holzer-Zelazewska, Vocational Education in the New EU Member States: Enhancing Labor Market Outcomes and Fiscal Efficiency, "World Bank Working Paper" 2007, no. 116, p. 26.

4 See e.g. Instytut Badań..., op. cit., p. 58. 
Pobrane z czasopisma Annales H - Oeconomia http://oeconomia.annales.umcs.pl

Data: 26/04/2023 14:34:06

COOPERATION BETWEEN VOCATIONAL SCHOOLS AND BUSINESS IN POLAND...

Table 1. The structure of researched entities according to the size and type of business against the general background of business entities in Lublin

\begin{tabular}{|l|c|c|c|}
\hline \multirow{2}{*}{ Specification } & \multicolumn{2}{c|}{ Surveyed group } & Lublin (2015) \\
\cline { 2 - 4 } & number & share (\%) & share (\%) \\
\hline Size & 40 & 42.1 & 96.1 \\
\hline micro & 23 & 24.2 & 3.0 \\
\hline small & 21 & 22.1 & 0.8 \\
\hline medium & 11 & 11.6 & 0.1 \\
\hline large & \multicolumn{3}{|c|}{} \\
\hline Sector & 36 & 37.9 & 16.4 \\
\hline Industry and construction & 59 & 62.1 & 83.2 \\
\hline Services & &
\end{tabular}

Notes: micro-enterprises employ up to 10 people, small - 10 to 49 , medium -50 to 249 , and large -250 or more.

Source: Author's own research and data from CSO in Poland.

In one of the questions, the employers were asked to indicate and sort by priority up to 5 actions which, in their opinion, should be taken to strengthen vocational training and to adjust it to the requirements of labor market. Figure 1 presents the total number of indications and the percentage of indications of actions considered the most significant. Most respondents indicated the need to increase the amount

$$
\text { indications for the most important action } \quad \text { all indications }
$$

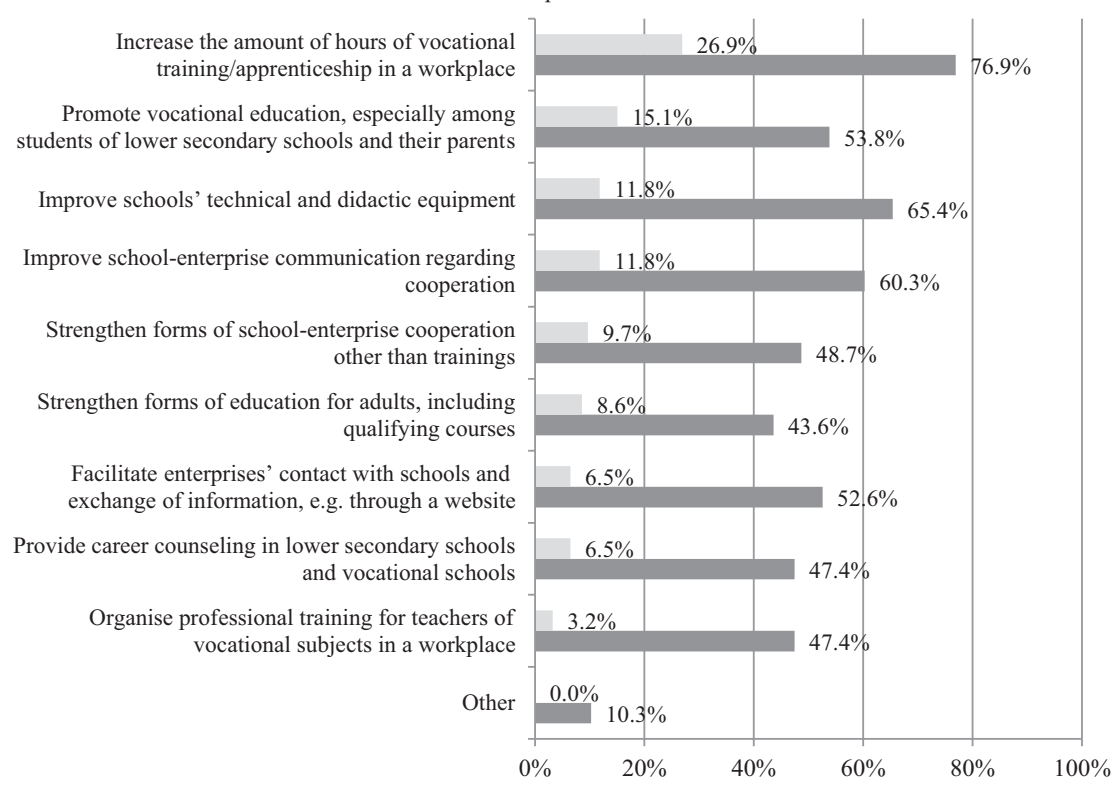

Figure 1. Important actions to be taken in order to strengthen vocational education and to adjust it to the requirements of labor market (expressed in \%)

Note: The sum of all indications does not add up to $100 \%$, because the respondents could select up to 5 options.

Source: Author's own research. 
of hours of vocational training/apprenticeship, and most frequently considered this activity as the most important. Interpreting such results, one can make several conclusions. Firstly, practical vocational training is, according to the employers, the basic and most valuable instrument allowing for the adaptation of education to the needs of labor market. Secondly, employers have revealed the need to increase the number of hours of practical vocational training. It should be noted that, within the reform of vocational education implemented since 2012, the duration of vocational education has been significantly increased ${ }^{5}$. Due to the fact that the surveyed employers cooperate with schools, their answers might reflect an actual need to further extend the practical training beyond the current established size.

The remaining responses are distributed more evenly among other forms of activity, both in terms of the total number of indications and the assigned rank. It can be argued that unimportant activities were not indicated or proposed. It is worth pointing out that the answers of medium and large enterprises were not significantly different from those of micro and small businesses.

Respondents were also asked to indicate up to 5 forms of cooperation between schools and enterprises that they considered the most valuable. Their preferences have been presented in Figure 2.

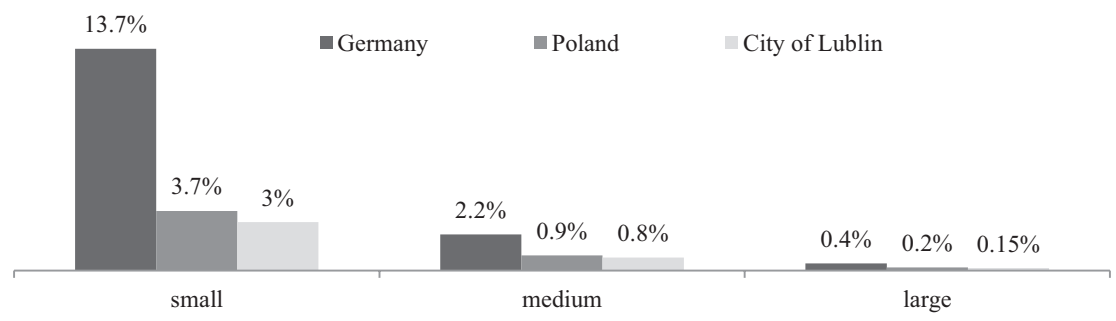

Figure 2. The most valuable forms of cooperation with vocational schools according to the employers (in \%)

Note: The sum of all indications does not add up to $100 \%$, because the respondents could select up to 5 options.

Source: Author's own research.

According to the surveyed employers from Lublin, organisation of trainings and apprenticeships is the most valuable form of cooperation with vocational schools. Over $90 \%$ of representatives of the surveyed enterprises chose this form of cooperation. Vocational training and apprenticeships were by far the most frequently indicated option both in industry and construction, and in services, regardless of the

5 For more details see: Rozporządzenie Ministra Edukacji Narodowej z dnia 7 lutego 2012 r. w sprawie ramowych planów nauczania w szkołach publicznych, Dz.U. 2012 poz. 204 (Regulation of the Ministry of National Education of 7 February 2012 on Framework Curricula in Public Schools, Journal of Laws 2012 item 204). 
size of the enterprise and the area of education covered by school-enterprise cooperation. While the dominant role of practical vocational training is not surprising, it is worth mentioning employers' preferences regarding other forms of cooperation. The second most popular option were courses and workshops for students, and the third one - conducting classes at school by enterprise employees. The participation of enterprise representatives in demonstration lessons was also popular. Therefore, the employers value different forms of practitioners' participation in school education.

Basing on the survey results, it can be concluded that, according to the surveyed employers, irrelevant curricula are no longer the main problem of vocational education. Cooperation in terms of development and modification of the school programs was ranked in the fourth place and opening new vocational courses in the eighth one. Such indication by employers cooperating with schools can be interpreted as a proof of generally successful curricula modernisation within the reform of vocational education implemented since 2012.

What is striking is the low percentage of indications for cooperation in organisation of external vocational exams which, according to the assumptions of the reform of vocational education, should play the key role in the verification of the quality of education and in education's adjustment to the needs of labor market. In focus group interviews organised in order to diagnose vocational education in the Lubelskie Voivodeship, the employers usually pointed out the considerable progress in drawing vocational exams closer to the real working environment after the reform of vocational education ${ }^{6}$. In contrast, other research suggests that employers, especially those who train students in the mechanical and mining field, assessed very poorly the significance of these exams in confirming graduate's professional competences ${ }^{7}$. It seems that there are two possible explanations for such low percentage of indications for this form of cooperation. Firstly, most employers may not be aware of that they can actively participate in vocational exams. Secondly, little interest in participation in the exams might stem from the negative evaluation of cooperation with schools in this field. Reasons for negative perception of vocational exams might be different. For instance, the entrepreneurs can be discouraged by procedural requirements (including obtaining powers of regional examination boards), extensive duration of the exams connected with employees' absence from work, or relatively small financial benefits for enterprise employees.

Another puzzling result is the last position of employers' support in equipping schools with technical and didactic materials, which often is a key problem for school headmasters. In the previously analysed question, the employers indicated the need to improve schools' technical and didactic equipment. Low number of indications in this question might stem from the fact that only few employers are prepared to

\footnotetext{
${ }^{6}$ Konwent Powiatów Województwa Lubelskiego, Diagnoza i plan rozwoju szkolnictwa zawodowego w województwie lubelskim do roku 2025, Lublin 2016.

7 M. Kicia, R. Zajkowski, op. cit., pp. 51-53.
} 
support schools in this respect, while the vast majority regards this issue as the sole responsibility of headmasters and local governments. It is worth noting that the size of a company does not differentiate the provided answers. This form of cooperation was, however, chosen more frequently by employers from those branches of industry in which adjustment of school equipment to the market realities is much more expensive than it is in the case of many kinds of services.

Only few employers indicated improvement of teachers' qualifications, especially for teaching vocational subjects. Such results can be explained in various ways. On the one hand, it might be a sign of a positive evaluation of teachers' knowledge. Still, other research on the subject often mentions negative opinions of enterprise representatives in this field ${ }^{8}$. On the other hand, it is more probable that low percentage of indications results from low conviction as to the effectiveness of different forms of improving teachers' qualifications, or from reluctance to engage in such initiatives. The latter might be due to the fact that teachers' training is a much more demanding task than organizing practical training for students.

In this situation it can be recommended that EU structural funds should be allocated primarily to these forms of cooperation between vocational schools and enterprises which are less attractive to employers. "Package" structure of projects is also worth considering. Such a structure could assume that in order to ensure cooperation favourable for the employers, they would have to engage in vocational exams or trainings for teachers. The overall balance of costs and benefits from the cooperation would still be favourable for enterprises.

Employers' willingness to cooperate with vocational schools should be proportional to the difficulties they experience in finding workers. Therefore, the enterprise questionnaire included questions concerning experience in the recruitment process. It turned out that the vast majority of respondents employed new workers in the period of three years prior to the survey. $78.9 \%$ of the surveyed enterprises, including almost all large and medium companies, searched for workers with vocational education within this period. What remains striking is the fact that, despite the possibility to recruit trainees, many employers seeking workers with vocational education signaled problems with recruitment. Only under $30 \%$ of employers seeking workers filled all vacancies with candidates having required professional qualifications, which can be interpreted as no difficulties in recruitment. $37 \%$ of respondents reported problems during the recruitment process: although they filled all positions, some of the new employees did not have the required qualifications. As many as one third of the respondents encountered serious problems with recruitment, so that they did not manage to fill all the vacant positions.

8 See e.g. Instytut Badań..., op. cit., p. 86; Konwent Powiatów..., op. cit. 


\section{Barriers to cooperation of vocational schools with employers - discussion}

In the light of the obtained results it is worth considering why enterprises in Lublin manifest limited willingness to engage in areas of cooperation significant for vocational education, despite experiencing recruitment problems. Reference to the conditions determining the success of German dual education system might be useful in attempting to address this issue.

First of all, the enterprise sector in the city of Lublin, and in Poland, is very fragmented. Micro-enterprises in Poland constitute $95.2 \%$ of all enterprises, in Lublin $-96 \%$, and in Germany $-83.6 \%$. In Lublin and in Poland the share of medium and large enterprises, which are potentially the most valuable partners for vocational schools, is more or less 2.5 times smaller than in Germany (see Figure 3).

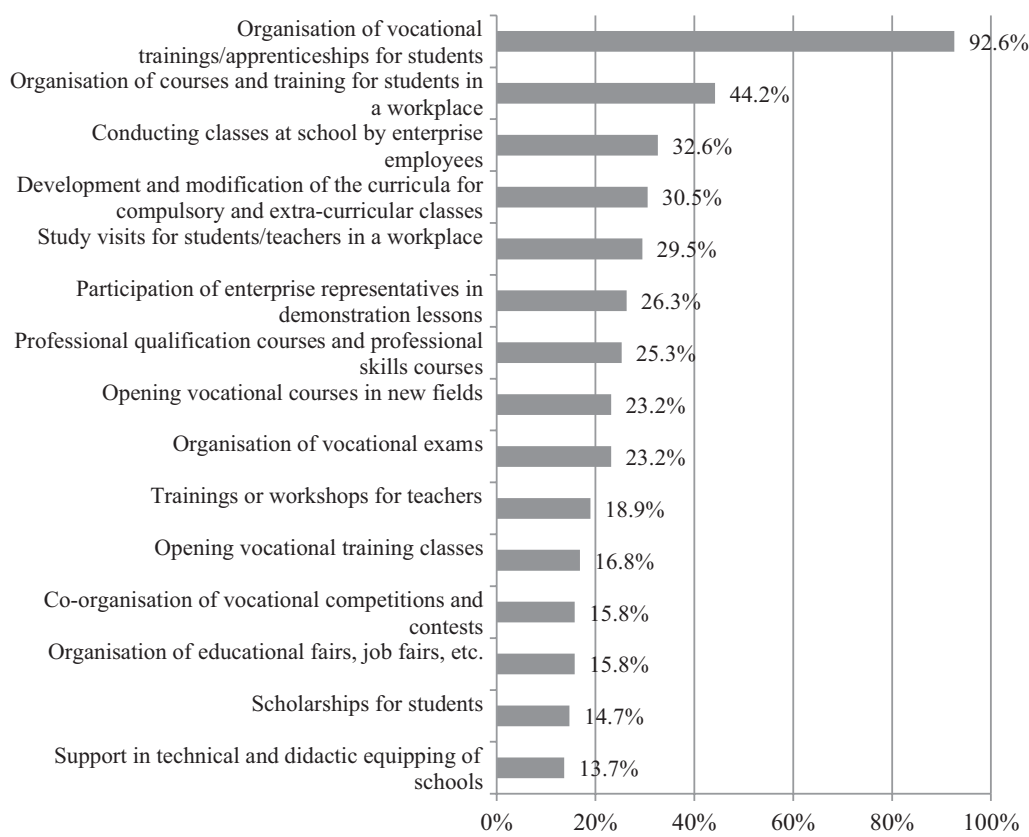

Figure 3. Percentage of small, medium and large enterprises in the city of Lublin, Poland and Germany

Source: Author's own study based on data from Eurostat (Poland and Germany) and CSO Local Data Bank (Lublin). Data for the year 2014.

The size of the company affects the structure of the costs and benefits from the cooperation with vocational schools. The possibility to recruit qualified workers is the most valuable benefit for the companies. In particular, the cooperation can help in adjusting education offered by schools to the needs of specific enterprise, gaining insight into students' skills and selecting the best candidates. Thanks to the network of contacts, the employers reduce the cost of recruitment, avoid wrong decisions in the 
selection of candidates, and reduce staff turnover. They also benefit from shortening the integration period for a new employee or from seasonal employment of young people during the holiday period ${ }^{9}$. Such benefits are, however, primarily enjoyed by medium and large enterprises, while smaller companies rarely recruit new employees. Instead of engaging in cooperation with schools, they prefer to obtain workers in an easier way, e.g. through acquaintances' recommendations or by recruiting them from the open market ${ }^{10}$. Fila, Rybińska, and Trzciński indicate that costs associated with taking on students for vocational training by micro and small companies (such as consumption of materials, tool damage, time devoted by staff to supervise students) are a bigger burden for these enterprises than for larger entities ${ }^{11}$. It is worth noting that the most significant benefits from enterprises' cooperation with schools are revealed in the longer term, while the structure of costs is dominated by short-term ones. Meanwhile, market strategy of small companies is more frequently based on adjustment to the current market situation, rather than to achieving long-term development goals.

Poorly developed cooperative bonds among enterprises are another barrier to the cooperation between employers and vocational schools in the city of Lublin and in Poland. Meanwhile, employers in Germany are well organised into associations and unions (the so-called corporatist model). For instance, for many years wage negotiations have been conducted via collective bargaining at industry level, i.e. between representations of employers in a given industry and the largest trade unions ${ }^{12}$. The presence of strong employers' associations facilitates cooperation with schools and the adjustment of education to the needs of labor market. In Poland, Lublin included, collective bargaining is decentralised, and wages are set at firm's level. Consequently, cooperative bonds between employers (e.g. trade associations or industrial clusters) are of little importance. In such conditions, the agreement of several employers in one branch of industry, e.g. to jointly order a new field of education, to delegate an employee to participate in vocational exams, or to establish a vocational education centre, is much more difficult.

Thirdly, recruitment problems of Polish employers are a relatively new phenomenon. For many years in Poland, the unemployment rate remained on a two-digit level, and unemployment rate in Lublin was one of the highest among the provincial cities in the country. Entrepreneurs in Lublin felt no incentive to cooperate with schools because they could easily recruit a worker on the open labor market ${ }^{13}$. A clear intensification

${ }^{9}$ See e.g. K. Hoeckel, Costs and Benefits in Vocational Education and Training, OECD, Paris 2008, pp. 3-12, Krajowy Ośrodek..., op. cit., pp. 214-215.

10 NBP, Badanie ankietowe rynku pracy. Raport 2016, Warszawa 2016, pp. 37-39.

11 J. Fila, A. Rybińska, R. Trzciński, Wspótpraca szkót zawodowych z przedsiębiorcami na przyktadzie Dziatania 9.2 PO KL, Instytut Badań Edukacyjnych, Warszawa 2014, pp. 11-12.

12 See: P. Maleszyk, Rynki pracy państw Unii Europejskiej w okresie kryzysu. Procesy dostosowawcze $i$ działania antykryzysowe, Wyd. UMCS, Lublin 2016, pp. 209-213 with cited literature.

${ }_{13}$ For more details see: Wojewódzki Urząd Pracy w Lublinie, Potrzeby i oczekiwania pracodawców. Raport z badań ilościowych pracodawców województwa lubelskiego zatrudniających co najmniej 10 pracowników, Lublin 2015. 
of recruitment problems occurred only after 2014; however, individual sectors and professions are not equally confronted with these problems. In Germany, labor shortage (especially in industry) has persisted for many years; therefore, the cooperation with schools, which allows for finding the needed workers, is among the enterprises' highest priorities.

Finally, cooperation of enterprises with vocational schools in Germany is rooted in the German system of values. As noted by Dziedziczak-Foltyn and Brzeziński in one of the most comprehensive reports on the perspective of dual education implementation in Poland, German "voluntary responsibility" of business for vocational education is probably unique in the world. ${ }^{14}$ This commitment translates into a willingness to share the cost of educating the youth. In Poland and in Lublin, employers' willingness to bear costs of dual education is significantly lower.

\section{Conclusions}

The analysis of the survey results confirms that incompatible interests of vocational schools and enterprises are one of the barriers to cooperation between the two. Employers are focused on increasing the number of hours of students' practical vocational training in the workplace. They also indicate the need to improve workshop equipment at schools, but are reluctant to cover the related costs. Rarely do they express willingness to participate in vocational exams and teachers' training. In general, employers are reluctant to undertake more costly and more demanding forms of cooperation with schools, despite growing recruitment problems.

Employers' limited willingness to engage in the areas of cooperation important for the vocational education stems not only from vocational education system itself, but also from structural features of the enterprise sector in Poland: its fragmentation, poorly developed cooperative bonds between enterprises, and the fact that cooperation with schools is not embedded in the system of values. The limited willingness to cover the costs of dual education is also due to the small scale of recruitment problems during most of the last two decades.

\section{Bibliography}

Canning, M., Godfrey, M., Holzer-Zelazewska, D., Vocational Education in the New EU Member States: Enhancing Labor Market Outcomes and Fiscal Efficiency, "World Bank Working Paper" 2007, no. 116.

Dziedziczak-Foltyn, A., Brzeziński, K., Kształcenie zawodowe i kształcenie dualne w Polsce i województwie łódzkim. Stan obecny i perspektywy rozwoju, HRP Group - ASM, Łódź 2013.

${ }^{14}$ A. Dziedziczak-Foltyn, K. Brzeziński, Ksztatcenie zawodowe i kształcenie dualne w Polsce $i$ województwie łódzkim. Stan obecny i perspektywy rozwoju, HRP Group - ASM, Łódź 2013, p. 79. 
Fila, J., Rybińska, A., Trzciński, R., Wspótpraca szkół zawodowych z przedsiębiorcami na przykładzie Działania 9.2 PO KL, Instytut Badań Edukacyjnych, Warszawa 2014.

Hoeckel, K., Costs and Benefits in Vocational Education and Training, OECD, Paris 2008.

Instytut Badań Rynku, Konsumpcji i Koniunktur, Absolwenci szkolnictwa zawodowego w Lublinie i Chetmie wobec sytuacji na rynku pracy, Warszawa 2010.

Jeruszka, U. (ed.), Unowocześnienie metod i form kształcenia zawodowego w Polsce. Diagnoza i oczekiwane kierunki zmian, IPiSS, Warszawa 2012.

Kabaj, M., System kształcenia zawodowego i kierunki jego doskonalenia w warunkach integracji $i$ wzrostu konkurencyjności: Diagnoza i elementy programu szerszego wdrożenia dualnego systemu kształcenia w Polsce, Związek Rzemiosła Polskiego, Warszawa 2010.

Kicia, M., Zajkowski, R., Uwarunkowania wspótpracy zasadniczych szkót zawodowych i pracodawców $w$ województwie lubelskim. Raport z badania kluczowego, Fundacja PAN, Lublin 2012.

Konwent Powiatów Województwa Lubelskiego, Diagnoza i plan rozwoju szkolnictwa zawodowego w województwie lubelskim do roku 2025, Lublin 2016.

Krajowy Ośrodek Wspierania Edukacji Zawodowej i Ustawicznej, Badanie funkcjonowania systemu kształcenia zawodowego w Polsce. Raport końcowy, Warszawa 2011.

Maleszyk, P., Rynki pracy państw Unii Europejskiej w okresie kryzysu. Procesy dostosowawcze i działania antykryzysowe, Wyd. UMCS, Lublin 2016.

NBP, Badanie ankietowe rynku pracy. Raport 2016, Warszawa 2016.

NIK, System szkolnictwa zawodowego, Warszawa 2016.

Rozporządzenie Ministra Edukacji Narodowej z dnia 7 lutego 2012 r. w sprawie ramowych planów nauczania w szkołach publicznych, Dz.U. 2012 poz. 204.

Wojewódzki Urząd Pracy w Lublinie, Potrzeby i oczekiwania pracodawców. Raport z badań ilościowych pracodawców województwa lubelskiego zatrudniających co najmniej 10 pracowników, Lublin 2015.

\section{Cooperation between Vocational Schools and Business in Poland: Employers' Perspective}

The article identifies the barriers in cooperation between vocational schools and employers, which are connected with the economic and social environment of schools. The main source of information on employers' perspective is a survey of employers cooperating with vocational schools in Lublin (Poland). The survey results shows that employers are focused on increasing the number of hours of students' practical vocational training in the workplace, but are reluctant to undertake more costly and more demanding forms of cooperation with schools, like participating in vocational exams, training teachers or providing equipment for school workshops. It was argued that employers' limited willingness to cooperate stems i.a. from fragmentation of the enterprise sector in Poland, poorly developed cooperative bonds between enterprises, and the small scale of recruitment problems during most of the last two decades.

\section{Wspólpraca szkół zawodowych z biznesem: perspektywa pracodawców}

W artykule zidentyfikowano bariery współpracy szkół zawodowych z pracodawcami, które są związane z otoczeniem gospodarczym i społecznym szkół. Głównym źródłem informacji o perspektywie pracodawców było badanie ankietowe pracodawców współpracujących ze szkołami zawodowymi znajdującymi się w Lublinie (Polska). Wyniki badań pozwalają stwierdzić, że pracodawcy dostrzegają potrzebę zwiększenia wymiaru czasowego zajęć praktycznych w zakładach pracy, jednak są niechętni do podejmowania bardziej kosztownych i wymagających form współpracy ze szkołami, jak udział w egzaminach zawodowych, szkolenie nauczycieli czy wsparcie wyposażenia szkolnych warsztatów. W opracowaniu stwierdzono, że ograniczona gotowość pracodawców do współpracy wynika m.in. z rozdrobnienia sektora przedsiębiorstw w Polsce, słabo wykształconych więzi kooperacyjnych między przedsiębiorstwami, a także niewielkiego nasilenia problemów rekrutacyjnych przez większą część ostatnich dwóch dekad. 